\title{
Inclusive Education Management in the Development of Cognitive Intelligence of Children
}

\author{
Rosyadi BR ${ }^{1}$, Hasan Baharun ${ }^{2}$, Dewi Asiya ${ }^{3}$ \\ DOI: $10.35445 /$ alishlah.v13i2.538
}

Info Artikel

Keywords:

Educational

Management;

Inclusion;

Cognitive Intelligence

Kata kunci:

Managemen

Pendidikan;

Inklusif;

Kecerdasan Kognitif

\begin{abstract}
Early childhood cognitive intelligence that has not been fully developed in inclusive schools needs serious attention, considering that this age is a crucial growth period and the golden age of children. This study aims to analyze and understand inclusive education management in children's cognitive intelligence in RA Al-Iman, and RA Tania. This research uses a qualitative approach with a case study. The data collection technique is done through interviews, observation, and documentation. The data analysis was carried out circularly, starting from the display power, data reduction, and concluding. The results showed that inclusive education in developing children's cognitive intelligence in both institutions was planned and systematic, starting from identifying the needs of inclusive education, designing inclusive education, implementing inclusive education that leads to cognitive intelligence, and assessing inclusive education. This research has implications for the importance of implementing an egalitarian education and refers to equal rights so that children can mingle, play, and get the same education without any differences.
\end{abstract}

\begin{abstract}
Abstrak
Kecerdasan kognitif anak usia dini yang belum mampu dikembangkan secara sempurna di sekolah inklusi perlu mendapatkan perhatian serius, mengingat pada usia ini merupakan periode pertumbuhan krusial dan masa emas anak. Penelitian ini bertujuan untuk menganalisis dan memahami managemen pendidikan inklusif dalam menumbuhkembangkan kecerdasan kognitif anak di RA Al-Iman dan RA Tania. Penelitian ini menggunakan pendekatan kualitatif jenis studi kasus. Teknik pengumpulan datanya dilakukan melalui interview, observasi dan dokumentasi. Analisis datanya dilakukan secara sirkuler, yang dimulai dari daya display, reduksi data dan penarikan kesimpulan. Hasil penelitian menunjukkan bahwa manajemen pendidikan inklusif dalam menumbuhkembangkan kecerdasan kognitif anak pada kedua lembaga tersebut dilakukan secara terencana dan sistematis, yang dimulai dari Identifikasi kebutuhan pendidikan inklusif, desain pendidikan inklusif, pelaksanaan pendidikan inklusif yang mengarah kepada kecerdasan kogitif, dan penilaian pendidikan iklusif. Penelitian ini memberikan implikasi pada pentingnya menerapkan pendidikan yang egaliter dan mengacu pada persamaan hak, sehingga anak dapat berbaur, bermain, serta memperoleh pendidikan yang sama tanpa ada perbedaan.
\end{abstract}

\footnotetext{
${ }^{1}$ Institut Agama Islam Negeri Jember, Indonesia

Email: rosyadibadar123@gmail.com

${ }^{2}$ Nurul Jadid University, Paiton, Probolinggo, East Java, Indonesia

Email: ha54nbaharun@gmail.com

${ }^{3}$ Nurul Jadid University, Paiton, Probolinggo, East Java, Indonesia

Email: desiasiya71@gmail.com
} 


\section{INTRODUCTION}

Early childhood education is a series of programmed and systematic activities that guide children from birth (age o) to 6 years (Nurmiyanti \& Candra, 2019; Ichsan \& Hutagalung, 2019). Children have specific characteristics that are different from adults. They are always full of energy, vitality, enthusiasm, and curiosity about what they see, hear and feel, as if they never stop exploring and keep on learning (Heliawati, 2019). Meanwhile, the character is one of the components that must be prepared, especially in facing the challenges of the 21st century (Dakir, 2019; Maryam, 2018; Widodo \& Nursaptini, 2020).

Inclusive education accommodates all students and provides equal opportunities for every child to learn in the classroom (Linh \& Azar, 2019), without differentiating between gender, intelligence, nature, physical and psychological (Hanur \& Avif, 2018; Ketenoğlu Kayabaşı, 2020). Inclusive education aims to humanize and fight discriminatory attitudes towards school institutions that refuse to accept children with special needs (Akrima, 2019; Ataç \& Taşçı, 2020). Inclusive education, in this case, includes a teaching system that combines children with special needs with typical children (Siddik \& Kawai, 2020). In this environment, the school environment provides freedom to support children with special needs (Dakir, 2014; Tarnoto, 2016)

Inclusive education is understood as education that seeks to collaborate with differences between students (including children with special needs) and regular students (Alfina \& Anwar, 2020; Bibiana et al., 2020). Conceptually and paradigmatically, inclusive education accepts every student, avoids negative labels, and plays a role in its operations involving related parties (Agustin, 2016; Baharun \& Astriani, 2019; Ramberg \& Watkins, 2020).

The facts that occurred in Raudlatul Athfal (RA) Al-Iman and Raudlatul Athfal (RA) Tania as sites for this research are. Some children with special needs (ABK) need unique and intensive guidance and assistance, but they do not get enough attention from the teacher, so their development is relatively slow. The indication is that children are less able to solve simple problems faced in everyday life, cannot think logically, cannot recognize cause and effect, lack initiative, are less able to recognize and mention letters, numbers and so on. Besides, the teacher also treats children in class A and class B at one level, which causes the child's cognitive development to be hampered.

Moreover, some teachers lack innovation in teaching. Learning seems monotonous and boring, which causes children to be unfocused and lack concentration, their eyesight everywhere. They are even indifferent to their teachers, which is indicated by talking to their friends. Noisy in class, playing alone, and so on. Teachers tend to teach what they are and lack the ghiroh to develop the potential of their heterogeneous children optimally. Of course, this causes a learning atmosphere that is not conducive and hinders children's cognitive development in both educational institutions.

Cognitive development is closely related to the quality of human life and is an aspect of development that emerges and develops rapidly at 24-72 months. Cognitive development refers to human thinking, including attention, memory, reasoning abilities, creativity, and language skills. Among them, 50\% of children's cognitive potential has been formed at the age of 4 years and is achieved at the age of 8 years to $80 \%$ of the total intelligence that will be achieved at the age of 18 years (Rahayu, Triyanti, \& Magdalena, 2014).

Cognitive development is determined at conception and is influenced by heredity or heredity. However, the development of this cognitive potential also depends on environmental factors and the maturity of the child in interacting with others to optimize development at the level of intelligence (Arimbi et al., 2018; Linh \& Azar, 2019; Waxman et al., 2019). Child development is closely related to family environmental factors (Saefudin, Ahmad, 2019).

Rahayu et al. (2014) suggest that stimulus is directly related to cognitive development because the stimulus has a very positive effect. Haryadi \& Aripin (2015) suggested that simulation games can train elementary school children's cognitive, affective, and psychomotor intelligence through design. Made et al. (2018) said that the development of cognitive abilities is a strategic point 
for early childhood development. This cognitive ability develops gradually in line with physical development and the nerves in the center of the nervous system (Nasution et al., 2019). Cognitive development is the internal processing of the human nervous system while thinking (Fardiah et al., 2019). Meanwhile, Zamroni et al. (2021) state that children's cognitive intelligence can be developed through optimizing the management of educational games made from waste.

This research shows the importance of developing cognitive intelligence so that children can solve problems related to remembering, thinking, understanding, reasoning, analyzing, synthesizing, planning, and so on. In developing this intelligence, appropriate management is needed, especially in developing children's cognitive intelligence in inclusive classes implemented in both institutions.

An inclusive education paradigm needs to be developed so that the desired learning objectives can be achieved. The importance of inclusive education has been conveyed by several researchers, including; Prasetyaningrum et al. (2017) stated that the main objective of inclusive education is to provide education to children with special needs and normal children together, according to their needs in the school closest to where they live, and according to their needs, to provide normal support without any discrimination. Dewi (2017) said that the inclusive education program is suitable for children with special needs and all children because basically, every child has characteristics, uniqueness, and natural diversity that exists in each child. Novianti (2019) stated that inclusive education could expand access to education for all groups, including children with special needs. At the same time, Setiawan \& Apsari (2019) stated that inclusive education needs to pay attention to various resources and conditions that support inclusiveness.

The exposure of this research indicates the importance of inclusive education in learning activities in schools that does not discriminate against the potential, competencies, physical and psychological aspects of students. Through this inclusive education, RA Al-Iman and RA Tania are planning and systematically trying to develop children's cognitive intelligence to serve as a medium to achieve the vision and mission of the institution.

Departing from some of these studies, researchers are interested in combining two different concepts, namely inclusive education and cognitive intelligence, in one research theme. It is unique and is a novelty in this research. This study aims to analyze and understand the management of inclusive education in improving cognitive intelligence carried out in RA Al-Iman and RA Tania.

\section{METHOD}

This research uses a qualitative approach to the type of case study. Qualitative research aims to understand the phenomena experienced by the research object, such as behavior, perception, motivation, action, etc., holistically and descriptively in language and text in a specific natural context and using various natural methods.

This study explicitly describes inclusive education management in developing children's cognitive intelligence in RA Al-Iman, Kraksaan, Probolinggo, and RA Tania, Paiton, Probolinggo. Research subjects and informants in this study are; principals, class teachers, special counselors, and parents of students. Observation and documentation are carried out to obtain accurate information about the theme being studied.

The data analysis technique was carried out systematically, starting with presenting data from interviews, observation, and documentation about inclusive education management in developing children's cognitive intelligence. Then proceed with data reduction adjusted to the focus of the study, so that the data is more specific and provides a basic overview of the research results. The final step is drawing conclusions that describe the overall results of the research findings.

\section{FINDINGS AND DISCUSSION}

The results showed that inclusive education management in developing cognitive intelligence in RA Al-Iman, Kraksaan, Probolinggo and RA Tania, Paiton, Probolinggo are as follows; 


\section{Inclusive Need Identification}

Identifying inclusive needs is the first step both educational institutions take to find out about the learning styles, conditions, and characteristics of students from an early age so that steps can be determined to form an inclusive class. Based on the results of the researchers' observations, it was found that the two institutions had started implementing inclusive education, which was evidenced by the difference between students with special needs, unique talents, and disabilities gathered in the same class. This is intended to provide opportunities for all students to get the same education and learning as other students in general.

\section{a. Learner identification}

There are several stages in identifying students with unique and normal needs. The first thing that these two institutions do is filling out forms by parents when registering their children. The form contains several questions that lead to several aspects: the child's physical, intellectual, psychological, and mental condition.

SHF (2021), as the principal of RA Tania Sumberanyar Paiton, said that the form of the student's guardian filled in did not represent the actual situation of the students. The school made further identification to find out the actual conditions experienced by students, namely, first, make physical observations on students see observations of faces, how to communicate and how to walk. Second, children who have a high level of difficulty during the teaching and learning process and do not reach the set value are suspected of having special needs.

RS (2021), as the principal of RA Al-Iman Bulu Kraksaan school, revealed that the purpose of identifying students is to find out the child's condition, the child's background, which is the provision for the teacher in determining to learn. The children can be handled from an early age through exceptional guidance or submitted to special needs teachers. The same thing was also conveyed by SLH (2021) as RA Tania's teacher, who said that every teacher was equipped with knowledge about the characteristics of children with special needs, starting from physical characteristics (face, body movements, and speech) and children's behavior when learning took root in class.

The informant's statement shows that the two institutions identify students to get accurate information to make decisions to develop children's potential, especially their cognitive intelligence.

\section{b. Identification of Teacher Needs}

Teachers in inclusive education must be ready in various ways, understand children with special needs, have methods and equipment for facilities and infrastructure that support teaching and learning activities. Broad insight into the development and development of children with special needs and normal children can provide appropriate development stimuli.

SHF (2021) said that teachers' efforts to provide broad insights were carried out by including all teachers in seminars or training on children with special needs. Raisusholihin (2021) added that every semester, the school made efforts to update the method by bringing in a psychologist or disability service unit in the context of direct handling of students and pilot material for teachers in duplicating the methods used by psychologists or the disability service unit.

In addition to insights and methods, what is no less important are the facilities and infrastructure that support teaching and learning activities, both for normal and for students with special needs. Facilities and infrastructure for normal and special needs have differences that emphasize the level of application and achievement of children with normal and special needs.

Based on researchers' observations, it was found that both institutions had the same facilities and infrastructure. These two institutions differentiate the learning facilities used by 
normal children and children with special needs. For example, the teacher uses color cards with standard sizes when introducing color cards to normal children. As for children with special needs, the teacher uses a color card with a jumbo size. It is done because children with special needs have a low level of concentration and vision everywhere. So with the use of jumbo media, children can see ultimately and broadly to avoid seeing in other directions.

\section{c. Identification of the Companion Teacher}

Recruitment of assistant teachers is carried out thoughtfully and not carelessly. This is because the accompanying teacher is required to educate children with special and normal needs simultaneously. Accompanying teachers are also the same as permanent teachers who have broad insight into children with special needs.

Schools that provide inclusive education need accompanying appropriate teachers and have insight in handling children with special and normal needs so that there are no differences and negative labeling. Companion teachers are needed in helping class teachers to manage conducive classroom conditions. Accompanying teachers also need education and training, developing insights in supporting mentoring for children with special needs, such as classroom teachers. RSM (2021), as a companion teacher at RA Tania, said, "Apart from attending seminars, parenting or training, I also share with fellow teachers, both companion teachers, and class teachers, in implementing learning that can increase the interest of students. FDL (2021), as a companion teacher for $\mathrm{RA} \mathrm{Al-Iman,} \mathrm{also} \mathrm{revealed} \mathrm{that} \mathrm{teachers} \mathrm{are} \mathrm{required} \mathrm{to} \mathrm{have} \mathrm{more}$ patience when dealing with children with special needs, especially as a companion teacher who is always ready to accompany children when they are at school until school hours.

The informant's statement indicated that the accompanying teacher in an inclusive class not only accompanies students during teaching and learning activities, but the accompanying teacher also has to supervise children outside of course until they return from school.

\section{d. Guardian Student Cooperation}

The guardian of the student is the leading and most important educator in the child's development. Therefore, he must seek information and knowledge about how to develop children's potential according to his expectations. Parents have a huge role in children's education. The success of children's education depends on family involvement. Therefore, cooperation or partnership from the school with the parents of students is needed.

SHF (2021) revealed that partnerships are developed in cooperation between guardians and teachers to achieve optimal child development. This partnership is essential, especially in inclusive education, where inclusive education includes all children in one unified aspect without distinction, so cooperation is needed. According to LIY (2021), the involvement of parents in school has many benefits, including; support academic achievement, increase attendance, awareness of a healthy life, and promote positive behavior.

Based on the findings in the field, the forms of cooperation or partnership carried out by both institutions are; first, cooperation activities in services for children with special needs, including; the existence of psychological examinations and play therapy. Second, educational cooperation including; visits students' homes, inviting parents to school, meetings with teachers, correspondence between schools and homes, and providing report cards.

\section{Inclusive Education Design}

Inclusive education design is a learning design with an inclusive nature, namely an effort to accommodate all the learning needs and barriers of very diverse students. RSH (2021), as the principal of the RA Al-Iman school, said that every educational institution must have an educational and learning design, especially in improving children's cognitive intelligence, considering that this is a fundamental need. Education and learning design is a projection of what is needed to achieve predetermined learning goals and objectives. 
Both institutions strive to place all education components, such as; foundations, principals, teachers, assistants, parents, and students, jointly develop a conducive educational environment for all children, including children with special needs, to develop their potential optimally. The design of inclusive education provides opportunities for children, especially those included in children with special needs, to participate in proper education and learning without paying attention to physical, emotional, mental, intellectual, and social disorders.

SHF (2021) said that inclusive classes were implemented in RA Tania. According to him, inclusive education is very concerned with responding appropriately to the heterogeneous learning needs of students. In designing inclusive education, we start with the admission of new students at the stage of admission of new students. The teacher makes initial identification of the students, who are included in the category of children with special needs, intelligent children, children with physical disabilities, etc. This identification will determine the learning needs that must be fulfilled, especially when developing children's cognitive intelligence.

According to FDL (2021), each school has different activities in planning inclusive education to improve children's cognitive intelligence. RA Al-Iman, in planning learning, first identifies the needs of students, whether there are students who have a mental, physical or psychological background, then modifies the learning and curriculum that is tailored to exist needs to achieve the desired goals. SLH (2021) said that the inclusive education curriculum used in his institution emphasizes all aspects of early childhood intelligence, but what is more emphasized is education that stimulates children's cognitive intelligence.

Departing from the informant's statement, the design of inclusive education in improving children's cognitive intelligence can be described. Figure 1 shows that student identification is carried out to determine the characteristics of student input, both from average students or students who have special needs, physical, mental and psychological limitations. After knowing the potential for student input, the principal and the teacher determine the learning needs, both direct and indirect. The final step is curriculum modification that leads to the development of children's cognitive intelligence.

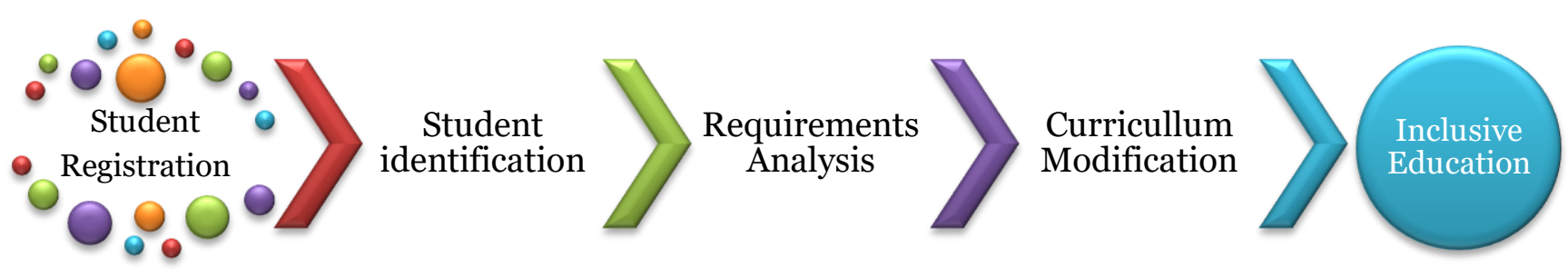

\section{Figure 1. Inclusive education design in improving children's cognitive intelligence in RA Al-Iman and RA Tania}

The inclusive education curriculum prepares learning patterns, guidance, and care with the initial stage. It includes making observations to find out what obstacles the child is experiencing, then carrying out an assessment, then planning the PPI (Individual Teaching Program) derived from the regular curriculum.

\section{Implementation of Inchsive Education Based on Cognitive Intelligence}

The application of inclusive education continues the planning or design of inclusive education developed by the two educational institutions. Based on RML's (2021) interviews as the RA Al-Iman teacher, "the implementation of inclusive education in RA Al-Iman emphasizes six aspects of child development, including the development of cognitive intelligence, both children with special and normal needs. In implementing inclusive education based on six aspects of development, teachers use a classical pattern. The classical pattern was chosen because it was easier for teachers to master the class, organize students' places, be more economical, and so on. Children with special 
needs are included to join their friends classically in the classroom to help children work together and mingle with normal children without having to differentiate between them, but still with the assistance of accompanying teachers.

Activities in inclusive education in developing intelligence in 6 aspects at RA Al-Iman include combining student activities in general with students with special needs in the same class. However, the difference tends to be an achievement. The activities are almost the same as those of children in general, except that it is more focused on social development and emotional development but still emphasizes intelligence on six aspects of development, especially in cognitive intelligence. According to KLF (2021), implementing the cognitive field is carried out by applying something real and concrete, such as recognizing colors with colored balls, numbers with number cards, recognizing animal names by inviting children to go directly to fields such as zoos.

RFT (2021), as a teacher at RA Tania, conveyed that the learning activities carried out could form groups or classics to develop cognitive intelligence. Implementation in the cognitive development aspect is carried out repeatedly, especially for children with special needs. The learning is carried out inside and outside the classroom, introducing the concept of numbers with number cards, introducing the concept of color by going directly to the schoolyard to see the color of leaves, flowers, trees, rocks, etc. Introduction to the environment through light walks in the school environment by looking at the social environment such as friends' houses, places of worship, transportation, and animals in the school environment.

The methods used by teachers in both institutions are; First, the storytelling method. The teacher explains learning by telling stories and interspersed with teacher creativity such as singing and clapping. The use of color concept recognition media, number concepts, and letter recognition concepts is also carried out in this storytelling method to focus on children being more focused and listening more to what the teacher says. The media can use APE (Educational Teaching Aids) such as; Color Balls, Number Cards, Letter Blocks, Paste Boards, etc. A teacher is in charge of guiding lessons, and two teacher assistants are in charge of guarding and accompanying the back, especially assisting children with special needs.

The second, the question and answer method. In the question and answer session, the teacher asks about the lessons that have been delivered. Teachers usually provoke cognitive development by utilizing media prepared to develop cognitive aspects such as; number cards, color balls, letter boards, and so on.

The results of field observations when learning took place, there were no learning media specifically for children with special needs. The existing educational game tools were general that could develop cognitive intelligence. However, teachers could adjust the use of media to the needs of children with special needs.

Learning activities are developed so that the child's learning experience is by the planned learning objectives that have been determined, especially in the aspects of cognitive development. The learning process is carried out through exploration based on themes. Students are given the flexibility and are introduced to new things to open their horizons with more varied and fun learning resources. Children's cognitive intelligence develops optimally according to children's age level and condition with special needs with fun learning.

\section{Inclusive Education Assessment}

NDF (2021) explained that the assessment is needed to determine the extent to which the student achievement is revised on the needs that need to be added or reduced in the management of inclusive education to develop cognitive intelligence in early childhood in his institution.

RMT (2021), as a teacher at RA Tania, said that the teacher conducts assessments using three techniques, such as making their notes in the form of anecdotal notes, especially in the cognitive development of each child, then assessing the work of the children's works such as drawing, collage, raising and others. Furthermore, the scale of developmental achievements is adjusted to the 
achievement of indicators that the school has determined. The method used in conducting the assessment is in the form of observation or observation methods, which is done by observing the behavior and activities of children in a given time or action.

The assessment system applied to both institutions is almost the same as the learning assessment in general. The assessment also involves parents of students so that they know the conditions of their children's needs. The aspects assessed for early childhood with special needs are socialization, emotions, concentration, fine motor skills, gross motor skills, language, independence, and cognitive.

The form of assessment is narrative or notes in the achievement indicators of children with special needs and general children, which still refers to the three assessment techniques for early childhood, namely anecdotal notes, work results, and developmental achievement scales. The scoring or evaluation system is carried out every day, then reprocessed into monthly assessments. Monthly assessments are used as an assessment archive that is manifested in a portfolio and used as a reference in semester assessments in the form of report cards. Evaluation is carried out objectively and adjusted to changes in learning outcomes, both children with special and general needs.

Starting from some of the research findings, it can be seen that inclusive education is a process of increasing the ability of the education system to reach all students so that it can be understood as the primary strategy for achieving education for all (Sartica, 2016; Tahir et al., 2019). Inclusive education is seen as a process of responding to the diverse needs of all children through increasing participation in learning, culture, and society and reducing exclusivity in and from education (Qodir et al., 2017; Robiyansah et al., 2020).

Every child is allowed to help each other, help each other, accept each other's different personalities and characteristics both physically and psychologically (Al-Shammari et al., 2019). Such handling cannot be separated from classification or "labeling," which leads to two paradoxical things, namely between regular children and children with special needs themselves, which affect the processes and consequences for each individual (on the two types of children).

One of the children's intelligence that is important to be developed through this inclusive activity is cognitive intelligence. A person who can increase his abilities through knowledge is called cognitive development (Aulia, 2019). Children's cognitive development occurs in a different order. This stage helps explain how children think, store information, and adapt to their environment (Karim \& Wifroh, 2014). Especially for children with special needs, their cognitive development needs to be stimulated and accompanied to achieve the desired development process.

Inclusive education management is formed to accommodate all students without having to differentiate between them, and make them mingle, accept each other, understand each other's weaknesses and strengths (Al-Shammari et al., 2019). The meaning of the success of the inclusion program is that the teacher will provide accommodation and support for the needs of all students in the classroom, not be too compulsive, and will not reduce student rights (Singh et al., 2020).

Implementing inclusive education in this field is not as easy as the theory. There are many obstacles and challenges. This requires mutual adaptation between inclusive students and regular teachers and their regular friends. This is usually caused by a lack of understanding about inclusive children because the behavior of inclusive students has limitations. Regular teachers' lack of understanding of the conditions of inclusive children will result in uncontrolled learning activities. Therefore, it is recommended that every regular teacher involved in teaching in an inclusive classroom must have the psychology of inclusive student personalities (Hasyim, 2013).

\section{CONCLUSION}

Inclusive education management needs to be designed in a planned and systematic manner to provide optimal services to normal and special students. Inclusive education management at RA Al-Iman and RA Tania can embrace all students in one unit, without differentiating between one another, so that they can develop their cognitive intelligence. The management of inclusive classes 
at both institutions is carried out through inclusive need identification, inclusive education design, inclusive education based on cognitive intelligence, and inclusive education assessment.

Inclusive education management that is applied to these two educational institutions, of course, cannot be generalized to all educational institutions at this age. Because each institution is different, it has its characteristics and uniqueness. It can be adjusted to each institution's causes, cases, and features of learners and environmental analyses. Therefore, this allows further researchers to study and research these themes with different cases and characteristics.

\section{REFERENCES}

Agustin, I. (2016). Manajemen Pendidikan Inklusi Di Sekolah Dasar Sumbersari 1 Kota Malang. Education and Human Development Journal, 1(1), 27-33. https://doi.org/10.33086/ehdj.v1i1.290

Akrima, T. L. (2019). Perbedaan Kemampuan Empati Anak Usia Dini Ditinjau Dari Pengelolaan Model Kelompok Pada Kelas Inklusi.

Al-Shammari, Z., Faulkner, P. E., \& Forlin, C. (2019). Theories-based Inclusive Education Practices. Education Quarterly Reviews, 2(2), 408-414. https://doi.org/10.31014/aior.1993.02.02.73

Alfina, A., \& Anwar, R. N. (2020). Manajemen Sekolah Ramah Anak Paud Inklusi. Al-Tanzim: Jurnal Manajemen Pendidikan Islam, 4(1), 36-47. https://doi.org/10.33650/altanzim.v4i1.975

Arimbi, Y. D., Saparahayuningsih, S., \& Ardina, M. (2018). 71 Meningkatkan Perkembangan Kognitif Melalui Kegiatan Mind Mapping. Jurnal Ilmiah Potensia, 3(1), 64.

Ataç, B. A., \& Taşçı, S. (2020). An investigation of prospective language teachers' knowledge and attitudes towards inclusive education in Turkey. International Journal of Curriculum and Instruction, 12(2), 359-373.

Aulia, R. (2019). Upaya Meningkatkan Kecerdasan Kognitif Anak Usia Dini Melalui Model Pembelajaran Beyond Center And Circle Time (Bcct) Sentra Balok Di Tkit 1 Qurrota A'yun Ponorogo.

Baharun, H., \& Astriani, S. A. (2019). Pendekatan Webbed Learning Pada Pembelajaran Tematik Terhadap Peserta Didik Inklusif Di Madrasah. Journal AL-MUDARRIS, 2(1), 79. https://doi.org/10.32478/al-mudarris.v2i1.220

Bibiana, R. I., Madrine, K., Eric, W., \& Simon, T. (2020). Policy strategies for effective implementation of inclusive education in Kenya. International Journal of Educational Administration and Policy Studies, 12(1), 28-42. https://doi.org/10.5897/ijeaps2019.0622

Dakir. (2014). Manajemen Layanan Pendidikan Siswa Berkebutuhan Khsusus Prespektif Religious, Filosofis, Yuridis dan Historis. Yogyakarta: K-Media.

Dakir. (2019). Manajemen Pendidikan Karakter: Konsep dan Implementasinya di Sekolah dan Madrasah. Yogyakarta: K-Media.

Dewi, N. K. (2017). Manfaat Program Pendidikan Inklusi Untuk AUD. Jurnal Pendidikan Anak, 6(1), 12-19.

Fardiah, F., Murwani, S., \& Dhieni, N. (2019). Meningkatkan Kemampuan Kognitif Anak Usia Dini melalui Pembelajaran Sains. Jurnal Obsesi: Jurnal Pendidikan Anak Usia Dini, 4(1), 133. https://doi.org/10.31004/obsesi.v4i1.254

Hanur, B. S., \& Avif, S. (2018). Melayani Dengan Hati : Menghapus Diskriminasi dan Segregesi antara Anak Reguler dengan Anak Berkebutuhan Khusus melalui Sekolah inklusif YBPK Kota Kediri. Jurnal Al-Hikmah, 6(1), 27-40.

Haryadi, T., \& Aripin. (2015). Melatih Kecerdasan Kognitif, Afektif, Dan Psikomotorik Anak Sekolah Dasar Melalui Perancangan Game Simulasi "Warungku." Andhapura, Jurnal Desain Visual \& Multimedia, 1(2), 39-50.

Hasyim, Y. (2013). Pendidikan Inklusif di SMK Negeri 2 Malang. Jurnal Kebijakan Dan Pengembangan Pendidikan, 1(2), 112-121.

Heliawati, A. K. R. (2019). Manajemen Pembelajaran Inklusi Pada Anak Usia Dini. Educhild: Jurnal Ilmiah Pendidikan, 3(1), 15-23.

Ichsan, A., \& Hutagalung, Y. (2019). Manajemen Anak Didik Growing PAUD Inklusi Yogyakarta. Proceedings of The 4th Annual Conference on Islamic Early Childhood Education, 4(1), 327336.

Karim, M. B., \& Wifroh, S. H. (2014). Meningkatkan Perkembangan Kognitif Pada Anak Usia Dini Melalui Alat Permainan Edukatif. Jurnal PG-PAUD Trunojoyo, 1(2), 103-113. 
Ketenoğlu Kayabaşı, Z. E. (2020). Teachers' Opinions on Inclusive Education. International Journal of Psychology and Educational Studies, 7(4), 27-36. https://doi.org/10.17220/ijpes.2020.04.003

Lailiyah, H. (2021). Interview.

Linh, P. H. T., \& Azar, A. S. (2019). A Comparative Study of the Inclusive Education Policy in Vietnam and Malaysia: Proposed Solutions for Sustainable Development Education in Vietnam. Education Quarterly Reviews, 2(3), 539-550. https://doi.org/10.31014/aior.1993.02.03.86

Made, N., Suryaningsih, A., \& Rimpiati, N. L. (2018). Implementation of Game-Based Thematic Science Approach in Developing Early Childhood Cognitive Capabilities. Jurnal Obsesi : Jurnal Pendidikan Anak Usia Dini, 2(2), 194-201. https://doi.org/10.31004/obsesi.v2i2.90

Maryam, S. (2018). Building Character Education Using Three Matra of Hasan Al-Banna'S Perspective in Pesantren. Jurnal Pendidikan Islam, 4(2), 51-62. https://doi.org/10.15575/jpi.v4i2.2422

Nadifah, U. (2021). Interview.

Nasution, N., Yaswinda, Y., \& Maulana, I. (2019). Analisis Pembelajaran Berhitung melalui Media Prisma Pintar pada Anak Usia Dini. Jurnal Obsesi : Jurnal Pendidikan Anak Usia Dini, 4(1), 240. https://doi.org/10.31004/obsesi.v4i1.311

Novianti, E. (2019). Membangun Budaya Sekolah Inklusi Dalam Perspektif Neurosains. Prosiding Seminar Nasional, 4(5), 53-58.

Nurmiyanti, L., \& Candra, B. Y. (2019). Kepemimpinan Transformasional dalam Peningkatan Mutu Pendidikan Anak Usia Dini. Al-Tanzim: Jurnal Manajemen Pendidikan Islam, 3(2), 13-24. https://doi.org/10.33650/al-tanzim.v3i2.646

Prasetyaningrum, S., Saraswati, P., Ni’matuzahroh, -, \& Firmanto, F. (2017). School Readiness Siswa Berkebutuhan Khusus Di Kelas Inklusi Tingkat Sekolah Dasar Kota Batu. Jurnal Psikologi Perseptual, 2(1), 48-67. https://doi.org/10.24176/perseptual.v2i1.2221

Qodir, A., Dakir, D., \& Umiarso, U. (2017). The Concept of Human Unity and Islamic Inclusive Education: A Study of KH. Imam Zarkasyi's Thought in Social Change. Journal of Islamic Studies and Culture, 5(2), 229-242. https://doi.org/10.15640/jisc.v5n2a6

Rahayu, S., Triyanti, S., \& Magdalena, Y. (2014). Pembelajaran di Pendidikan Anak Usia Dini dengan Perkembangan Kognitif pada Anak. Jurnal Kesehatan Masyarakat Nasional, 8(6), 243-249.

Raisusholihin. (2021). Interview.

Ramberg, J., \& Watkins, A. (2020). Exploring inclusive education across Europe: some insights from the European Agency Statistics on Inclusive Education. FIRE: Forum for International Research in Education, 6(1), 85-101. https://doi.org/10.32865/fire202061172

Robiyansah, I. E., Mudjito, M., \& Murtadlo, M. (2020). The development of inclusive education management model: Practical guidelines for learning in inclusive school. Journal of Education and Learning (EduLearn), 14(1), 80-86. https://doi.org/10.11591/edulearn.v1411.13505

Rusmiyati. (2020). Interview.

Saefudin, Ahmad, A. W. (2019). Pola Asuh Inklusif Keluarga Seagama dan Beda Agama: Sebuah Model Pendidikan Toleransi Di Desa Bondo Jepara. Jurnal Penelitian Ilmu Sosial Dan Kegamaan Islam, 16(2), 123-137. https://doi.org/10.19105/nuansa.v16i2.2534

Saleha, L. (2021). Inerview.

Sartica, D. (2016). Evaluasi Penyelenggaraan Program Pendidikan Inklusif Di Kota Palangka Raya. Jurnal Manajemen Pendidikan, 3(1), 49-66.

Setiawan, E., \& Apsari, N. C. (2019). Pendidikan Inklusif: Upaya Mewujudkan Kesetaraan dan Non Diskriminatif di Bidang Pendidikan bagi Anak Dengan Disabilitas (AdD). Sosio Informa, 5(3), $188-198$.

Shafiah. (2021). Interview.

Siddik, M. A. B., \& Kawai, N. (2020). Government primary school teacher training needs for inclusive education in Bangladesh. International Journal of Whole Schooling, 16(2), 35-69.

Singh, S., Kumar, S., \& Singh, R. K. (2020). A Study of Attitude of Teachers towards Inclusive Education. Shanlax International Journal of Education, 9(1), 189-197. https://doi.org/10.34293/education.v9i1.3511

Tahir, Khazima Ed.D., Doelger,Brian Ed.D., and Hynes, M. E. D. (2019). A Case Study on the Ecology of Inclusive Education in the United States. Journal for Leadership and Instruction, (Spring), 17-24. Retrieved from https://files.eric.ed.gov/fulltext/EJ1222244.pdf

Tarnoto, N. (2016). Permasalahan-Permasalahan Yang Dihadapi Sekolah Penyelenggara Pendidikan 


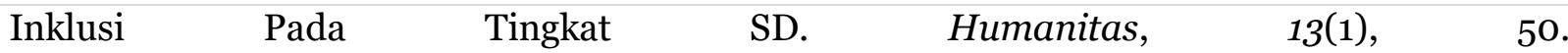
https://doi.org/10.26555/humanitas.v13i1.3843

Waxman, S., Figlio, D., Garfield, C., Jordan, N., Sabol, T., Davis, M. M., ... Bridgman, A. (2019). Social Policy Report Brief. 32(1).

Widodo, A., \& Nursaptini. (2020). Problematika Pendidikan Karakter Anak Berkebutuhan Khusus (Studi Kasus Terhadap Sekolah Dasar Penyelenggara Pendidikan Inklusif di Lombok Tengah). Jendela Pendidikan, Jurnal Ilmiah Keguruan Dan Ilmu Pendidikan, 9(2), 129-135.

Zamroni, Amir, \& Saleha, L. (2021). Pengelolaan APE Berbahan Limbah untuk Meningkatkan Kecerdasan Kognitif Anak. Jurnal Obsesi : Jurnal Pendidikan Anak Usia Dini, 5(2), 13821395. https://doi.org/10.31004/obsesi.v5i2.763 